\title{
POPULATIONS AND HABITAT RELATIONSHIPS OF PIUTE GROUND SQUIRRELS IN SOUTHWESTERN IDAHO
}

\author{
Karen Steenhof ${ }^{1,4}$, Eric Yensen ${ }^{2}$, Michael N. Kochert ${ }^{1}$, and Kenneth L. Gage ${ }^{3}$
}

\begin{abstract}
Piute ground squirrels (Spermophilus mollis idahoensis) are normally above ground from late January until late June or early July in the Snake River Birds of Prey National Conservation Area in southwestern Idaho. In 2002 they were rarely seen above ground after early May. Because of the ecological importance of ground squirrels for nesting raptors and other species, we sought to determine the reasons for their early disappearance. We sampled 12 sites from January 2003 through March 2003 to determine if a population crash had occurred in 2002. Tests indicated that Piute ground squirrels had not been exposed to plague within the past year. The presence of yearlings in the population indicated that squirrels reproduced in 2002 and that at least some yearlings survived the winter. Both yearling and adult squirrels appeared to be reproducing at or above normal rates in 2003. The most plausible explanation for the early disappearance of Piute ground squirrels in 2002 is that squirrels entered seasonal torpor early in response to a late spring drought. In addition, the breeding chronology of squirrels may have shifted during the past 2 decades in response to climate change and/or habitat alteration. Shrub habitats provide a more favorable and stable environment for squirrels than grass habitats. Squirrel abundance was higher on live-trapping grids with sagebrush than on grids dominated by grass, and squirrel masses were higher at sites dominated by shrubs and Sandberg bluegrass (Poa secunda). Densities in big sagebrush (Artemisia tridentata) were within the ranges reported for earlier years, but densities in grass were lower than previously reported. Low densities at grassland sites in 2003 support other findings that drought affects squirrels in altered grass communities more than those in native shrub habitats. Long-term shifts in ground squirrel breeding chronology may have implications for raptors that depend on them for food.
\end{abstract}

Key words: abundance, disease, drought, habitat, Piute ground squirrel, plague, populations, reproduction, sagebrush, Spermophilus mollis.

Piute ground squirrels (Spermophilus mollis idahoensis) are key prey of raptors and other predators in the Snake River Birds of Prey National Conservation Area (hereafter NCA). They are a critical food resource for Prairie Falcons (Falco mexicanus), and important prey for Red-tailed Hawks (Buteo jamaicensis), Ferruginous Hawks (B. regalis), other raptors, Common Ravens (Corvus corax; Steenhof and Kochert 1985, 1988), badgers (Taxidea taxus; Messick and Hornocker 1981), western rattlesnakes (Crotalus viridis), and gopher snakes (Pituophis catenifer; Diller and Johnson 1988). Ground squirrels also loosen, aerate, move, and mix soils, thereby increasing primary productivity. Their loss may therefore have serious ecological consequences (Yensen and Sherman 2003). Like many other species of ground squirrels, Piute ground squirrels are active above ground for a relatively short period of time ( $<6$ months) each year. During the hot summer months, Piute ground squirrels enter seasonal torpor and remain in their burrows until January or February. Adult males are the first to reenter seasonal torpor (usually beginning in May), followed by adult females, and finally juveniles (typically in late June; Smith and Johnson 1985). The breeding chronology of Prairie Falcons is closely timed to match the squirrel's annual cycle (USDI 1996), so changes in both squirrel abundance and reproductive chronology can affect how much food is available to nesting falcons.

Since 1980 ground squirrel habitat in the NCA has changed drastically because of the cumulative effects of wildfires, livestock grazing, drought, and military training; large areas of native shrub communities have been converted to homogeneous stands of nonnative annual grasses (USDI 1996). Populations of Piute ground squirrels are unstable in the NCA (Yensen et al. 1992). They were high in southern

\footnotetext{
${ }^{1}$ USGS Snake River Field Station, Forest and Rangeland Ecosystem Science Center, 970 Lusk Street, Boise, ID 83706. ${ }^{2}$ Department of Biology, Albertson College, 2112 Cleveland Blvd., Caldwell, ID 83605.

${ }^{3}$ Division of Vector-borne Infectious Diseases, Centers for Disease Control and Prevention, Box 2087, Fort Collins, CO 80522

${ }^{4}$ E-mail: karen_steenhof@usgs.gov
} 
Idaho in 1999, and very high in 2000, possibly reaching record levels (E. Yensen field notes, Yensen 2000). Piute ground squirrels were abundant in March and April of 2002, but > 15 scientists and technicians saw few squirrels in the NCA after early May 2002, even though survey crews visited the study area almost daily from April through the end of June (Yensen field notes; K. Steenhof and M.N. Kochert personal observation; D.L. Quinney and J.H. Doremus personal communication).

Land managers were interested to know what might have caused the early disappearance of Piute ground squirrels in 2002. The early disappearance may have resulted from reproductive failure, high squirrel mortality, early entry into seasonal torpor, or any combination of these 3 events. Reproductive failure could have accounted for early disappearance, because females that fail to produce litters fatten and immerge earlier than normal (Smith and Johnson 1985). Juveniles are usually the last to immerge, so the absence of juveniles could have explained the early disappearance of squirrels. Increased mortality might have been associated with widespread starvation, increased predation, poisoning, plague, or other unknown disease organisms. The purpose of this study was to assess the population status of Piute ground squirrels at emergence from seasonal torpor in 2003. We hoped to determine if squirrels had reproduced in 2002 and if extensive mortality had occurred. We also hoped to assess whether mortality had been similar among age classes and habitat types. Specifically, our 5 objectives were to (1) assess body mass and condition of surviving Piute ground squirrels in spring 2003, because low body masses might indicate that squirrels were food stressed and that starvation may have occurred; (2) evaluate whether Piute ground squirrels reproduced in 2002 by determining the age class structure of surviving Piute ground squirrels, because yearling-toadult ratios might indicate whether 2002 reproduction was below normal or if age-specific overwinter mortality had occurred; (3) determine if surviving Piute ground squirrels had elevated plague antibody titers in spring 2003 and if fleas collected from the squirrels were plague positive; (4) test squirrels for other possible parasites and diseases; and (5) estimate the abundance of Piute ground squirrels in different habitats within the NCA.

\section{Methods}

We established 12 study sites in the northwestern part of the NCA $\left(42^{\circ} 50^{\prime} \mathrm{N}, 115^{\circ} 50^{\prime} \mathrm{W}\right)$. Sites were selected from among 26 used in a 1994 study that estimated population density of Piute ground squirrels (Watts and Knick 1996). Selection criteria ensured that sites would (1) represent high, medium-high, and medium-low potential habitat for ground squirrels, defined by a logistic function of perennial native grass cover (Watts and Knick 1996); (2) represent 3 different geographic strata of the NCA (west, west central, and east central); (3) be reasonably accessible, have relatively homogeneous vegetation, and be relatively free from shooting and other disturbance; and (4) be distributed as pairs physically close enough to permit a 2-person crew to trap at 2 sites per day. We relocated each of the 12 sites using a GPS.

At each site, we set up a $6 \times 8$ live trapping grid with $13 \mathrm{~cm} \times 13 \mathrm{~cm} \times 41 \mathrm{~cm}$ Tomahawk live traps (Model 201, Tomahawk Live Trap Co., Tomahawk, WI) spaced at 30-m intervals. Each trapping site was $150 \mathrm{~m} \times 210 \mathrm{~m}$ for a total area of 3.15 ha. To make trap positions easy to locate, we marked the corners of each grid with steel " $\mathrm{t}$ " posts with lathe strips attached to the tops when it was difficult to see the posts from the other end of the trap line. Technicians placed traps baited with apple at the nearest hole-cluster within $5 \mathrm{~m}$ of the grid point. We prebaited each site with pieces of apple for 2-3 days prior to the 1st trapping session at each grid.

Live-trapping began on 11 February 2003 and continued through 13 March 2003. Two crews of 2 technicians trapped at 2 grids each per day, for a total of 4 grids per day. Each site was trapped on 6 different days. We tried to set traps at each grid for 2 consecutive days in each of 3 sessions, but weather and other scheduling constraints forced us to postpone trapping on some days. Trapping started in early morning when ground squirrels started their morning activities. The exact time shifted according to sunrise and weather conditions, and field crews adjusted their schedules appropriately. We conducted live-trapping on days when weather was suitable for trapping all day. On days when weather conditions were poor for part of the day, we focused on collecting specimens for necropsy (see below). 
We checked traps 3 times each day, at least once every 2 hours. Our trapping and handling procedures followed animal care protocol guidelines approved by Boise State University (IACUC Number 692-02-012). We approached traps with squirrels slowly, covered them with cloth, and carried them to the processing point. Squirrels were placed in a 3.8-L (1-gal) plastic jar with a swab of isoflurane. As soon as the squirrel lost consciousness, it was removed and combed for fleas. Fleas also were anesthetized by the isoflurane, making it easier and safer to transfer them to vials filled with $70 \%$ ethanol. We marked all captured squirrels with passive integrated transponders (PIT tags, Biomark Inc., Boise, ID; Schooley et al. 1993) by injecting one TX$1400 \mathrm{~L}$ tag $(11.5 \mathrm{~mm} \times 2.1 \mathrm{~mm})$ into each squirrel subcutaneously in the nape of the neck. We used a Biomark pocket reader to confirm the unique identification number. We assessed the reproductive status of squirrels based on evidence of pregnancy, lactation, or descended testes. We weighed all squirrels to the nearest gram and recorded the coordinates of each capture location using a GPS.

We established a companion site about $1-1.5 \mathrm{~km}$ from each live-trapping grid to collect specimens for necropsy. These sites were in the same vegetation type as their companion trapping grids and were just beyond normal dispersal distance $(\sim 1 \mathrm{~km})$ from the grids. Collection of specimens began on 29 January 2003 and continued through 8 March 2003. We used focal animal sampling (Yensen and Sherman 2003) to collect squirrels at the companion sites. Captured squirrels were anesthetized in a 3.8-L plastic jar containing a cotton ball soaked with isoflurane and euthanized by injecting $50 \mathrm{~mL}$ supersaturated potassium chloride into the heart. We did not euthanize squirrels if they showed obvious signs of lactation. We collected fleas by combing the squirrel and placing anesthetized fleas in a $70 \%$ ethyl alcohol solution. We drew blood from the abdominal cavity with a micropipette; sometimes it was necessary to nick the liver with a scalpel to increase blood flow. We removed the spleen and collected a small piece of liver from each animal. Squirrels were weighed and frozen for later analysis. All tissue samples were placed in separate labeled plastic containers, placed on dry ice in the field, and then stored at $-80^{\circ} \mathrm{C}$ until analyzed. We recorded coordinates at all capture locations using a GPS. Standard museum specimens were prepared from all individuals collected and were deposited in the Albertson College Museum of Natural History. Entire reproductive tracts of all sacrificed females were preserved in formalin, and uterine placental scars and embryos were counted using a microscope. Litter size was estimated from counts of visible embryos. Skulls were cleaned and measured; the age of each individual was estimated using tooth wear criteria (Yensen 1991). We considered individuals with tooth wear class 2 to be yearlings (squirrels in their 2 nd season) and classes $3-5$ to be adults.

Fecal pellets from trapped squirrels were stored at $-80^{\circ} \mathrm{C}$ until they could be analyzed at the Wildlife Habitat Nutrition Laboratory at the Department of Natural Resources, Washington State University. Each sample was ground to approximately $1 \mathrm{~mm}$ and dried at $100^{\circ} \mathrm{C}$ overnight prior to analysis. Percent fecal nitrogen was determined on an oven-dry basis using the Kjeldahl nitrogen procedure.

We cultured blood samples for Yersinia pestis and Bartonella and evaluated serum for Y. pestis antibodies. Approximately $100 \mu \mathrm{L}$ of each squirrel blood sample was suspended in an equal volume of brain heart infusion broth (BHI) and then streaked on blood agar plates as described by Kosoy et al. (2000) and Chu (2000). Plates were then monitored for growth over the next 20 days. Serum also was separated from squirrel blood samples and tested for antibodies to the $Y$. pestis F1 capsular antigen (cafl) by passive hemagglutination assay (Chu 2000).

We tested fleas collected from ground squirrels by multiplex PCR for evidence of $Y$. pestis or Bartonella infection using primers and methods described by Stevenson et al. (2003). Fleas were first identified to species, placed in a plastic vial containing $100 \mu \mathrm{L} \mathrm{BHI}$, and then triturated in a mixer mill. A total of $2.5 \mu \mathrm{L}$ of the triturated flea suspension was then removed and added to $47.5 \mu \mathrm{L}$ of a PCR master mix contained in a $100-\mu \mathrm{L}$ plastic vial. The vial with the sample and PCR master mix was then placed in a thermocycler and subjected to the following PCR protocol: (1) initial denaturation at $95^{\circ} \mathrm{C}$ for 5 minutes; (2) 35 cycles of denaturation at $95^{\circ} \mathrm{C}$ for 1 minute; (3) annealing at $56^{\circ} \mathrm{C}$ for 1 minute; (4) primer extension 
at $72^{\circ} \mathrm{C}$ for 1 minute; and (5) a final primer extension at $72^{\circ} \mathrm{C}$ for 10 minutes. Appropriate positive and negative control samples were used during all PCR assays. Following completion of the PCR protocol, samples were analyzed by electrophoresis on agarose gels using standard protocols to determine whether Y. pestis or Bartonella spp. DNA had been amplified.

We sampled vegetation on each of the livetrapping grids using a line-point intercept technique (Herrick et al. 2005). Within each grid we randomly selected starting points in rank order that did not fall within $30 \mathrm{~m}$ of each other or within $20 \mathrm{~m}$ of the grid's boundary. We established a 20-m transect at a randomly selected azimuth from each starting point and sampled each transect every $0.5 \mathrm{~m}$ (40 points). Using a cloth measuring tape, we dropped a pin vertically at each point along the transect. We sampled plant species composition and canopy cover at 3 canopy layers (shrub, herbaceous, and substrate). At each point we recorded the species of plant that touched the pin and whether it was alive or dead. We classified the substrate on which the pin touched as bare ground, litter, microbiotic crust, or rock. We calculated running means of the 4 most abundant categories to assess the number of sample units necessary to determine vegetation characteristics. Major categories included (1) big sagebrush (Artemisia tridentata), (2) winterfat (Krascheninnikovia lanata), (3) other shrubs (budsage [A. spinescens], shadscale [Atriplex confertifolia], and spiny hopsage [Grayia spinosa]), (4) Sandberg blue grass (Poa secunda), (5) cheatgrass (Bromus tectorum), (6) other forbs and grasses, and (7) substrate.

We used the POPAN model in Program MARK (White and Burnham 1999) to estimate the total number of squirrels by sex, habitat, and on all 12 grids combined. We used a model described by Schwarz and Arnason (1996) that provides a parameterization of the Jolly-Seber model. We constrained the fully open model to fit the robust design so it was essentially a hybrid of open/closed models. To estimate the effective trapping area for density estimates, we calculated a strip width to be added to each grid, using half of the mean maximum distance moved for all squirrels captured at $>1$ location (i.e., $\geq 15 \mathrm{~m}$ apart). We computed effective trap areas using formulas recommended by Otis et al. (1978) for each sex and for both sexes combined. Means are reported \pm 1 standard deviation $(s)$.

\section{RESULTS}

We classified 6 trapping grids as shrub sites and 6 as grass sites based on the presence or absence of shrub cover (Fig. 1). Shrub sites contained 4\%-33\% shrub cover, and big sagebrush was the only shrub recorded on transects (Table 1, Fig. 1). Percent cover of Sandberg bluegrass and cheatgrass ranged from $0 \%$ to $38 \%$ in the shrub sites. The grass sites contained 0\%-48\% Sandberg bluegrass and between $0 \%$ and $54 \%$ cheatgrass. Overall, 5 sites were dominated by cheatgrass, an exotic annual, and 6 sites were dominated by Sandberg bluegrass, a native perennial important in ground squirrel diets (Fig. 1). Grids 47, 71, and 613 contained the most cheatgrass cover ranging between $49 \%$ and $54 \%$. Grid 246 had little total vegetative cover $(30 \%)$ and consisted mainly of curveseed butterwort (Ceratocephala testiculata, formerly known as bur buttercup) and other weeds.

We captured 111 different individuals $(80$ females and 31 males) on 11 of the 12 livetrapping grids. No squirrels were caught on Grid 47. The female-to-male ratio among captured squirrels was 2.58:1. Sixty-seven of the squirrels were recaptured at least once during the study. One individual was trapped 10 different times (including multiple captures on the same day). Only 1 squirrel was trapped on all 6 trapping days, 1 was trapped on 4 days, 9 were trapped on 3 days, 29 were trapped on 2 days, and 71 were captured on only 1 day, for a total of 166 independent squirrel encounters. Total numbers of captures, as well as number of individual squirrels caught, were highest on Grids 141 and 39 (Table 1).

The number of squirrels captured on 6 grids with sagebrush $(n=82)$ was significantly higher than the number trapped on 6 grids with no shrub cover $(n=29$; binomial test: $P$ $<0.001$ ). Number of individuals captured on the 12 grids did not correlate significantly with percent sagebrush cover $(r=0.47, P=0.12)$, Poa cover $(r=0.32, P=0.31)$, or the amount of "bare ground" ( $r=-0.05, P=0.89)$, but there was a significant inverse relationship between number of squirrels captured and percent cheatgrass cover $(r=-0.66, P=0.02)$ 


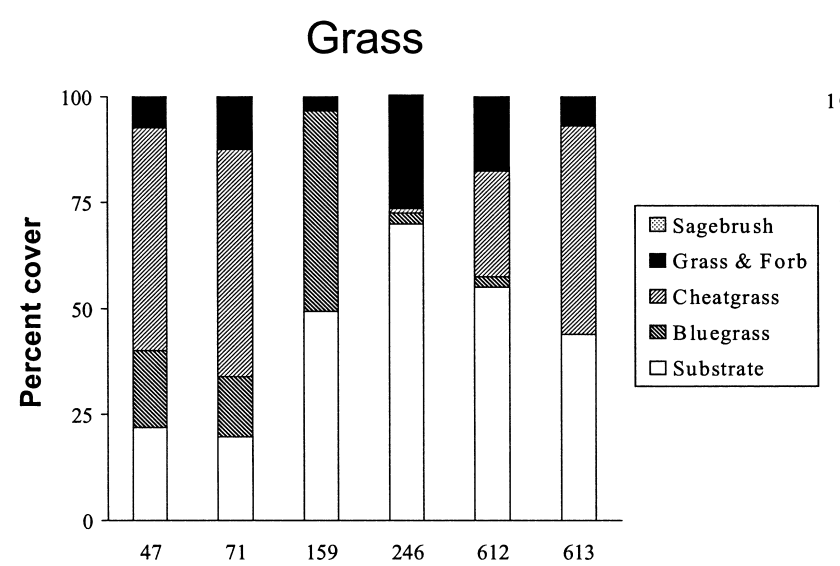

Grid number
Shrub

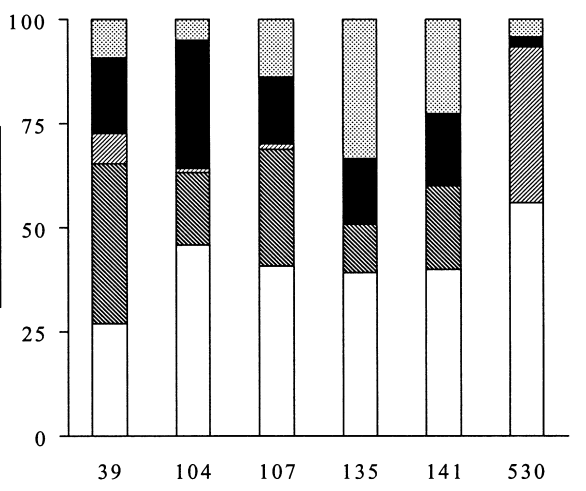

Grid number

Fig. 1. Percent cover of big sagebrush, other grasses and forbs, cheatgrass, Sandberg bluegrass, and substrate (bare ground, litter, microbiotic crust, and rock) in each trapping grid as determined by the line-point intercept method in 2003. Each bar shows the mean for all transects in each grid. Grids were grouped in either shrub or grassland types based on the presence or absence of shrubs.

and a weak relationship between number of squirrels captured and combined sagebrush and bluegrass cover $(r=0.51, P=0.09)$.

Of 80 females captured on live-trapping grids, 63 were either pregnant or lactating at some time during the trapping period, and 17 showed no signs of being reproductive. Fiftytwo of 62 females $(84 \%)$ in shrub habitats were reproductive, and 11 of 18 females $(61 \%)$ in grass habitats were reproductive $\left(\chi^{2}=3.92\right.$, $P=0.05)$. Testes of males trapped on grids were scrotal or semiscrotal in 14 individuals at the time of first capture, and nonscrotal in 17 . Most of the nonscrotal males (14) were from grids in shrub habitats and were likely yearlings.

Of squirrels that moved $\geq 15 \mathrm{~m}$ between trap locations, males moved farther $(66.7 \pm$ $42.3 \mathrm{~m}, n=11)$ than females $(48.6 \pm 28.7 \mathrm{~m}$, $n=23$ ). Both sexes combined moved a mean of $54.4 \pm 34.2 \mathrm{~m}(n=34)$. Adding a strip width of $27 \mathrm{~m}$ to our grids yielded an effective trapping area of 5.3 ha per grid or a total sampling area of 63.8 ha. Consistent with the distances moved between trapping events, effective trapping areas were larger for males (70.4 ha) than females (60.7 ha). We used the same effective trapping areas for both grass and shrub sites because $t$ tests showed no differences in mean maximum distances moved by either males $(t=$
$1.53 \mathrm{df}=9, P=0.22)$ or females $(t=1.49, \mathrm{df}$ $=21, P=0.12)$ in the 2 habitat types.

The estimated number of ground squirrels on all grids combined, based on capture/ recapture analysis, was 182 (Table 2), for an overall density of 2.85 squirrels $\cdot \mathrm{ha}^{-1}$. Estimated densities were higher on shrub grids (4.64 squirrels $\cdot \mathrm{ha}^{-1}$ ) than on grass grids (1.07 squirrels $\cdot \mathrm{ha}^{-1}$ ), and females were more abundant than males in both habitat types. The estimated overall sex ratio, 2.71:1, was slightly higher than that obtained from number of captures.

Using focal animal sampling, we captured 55 squirrels ( 27 females and 28 males) at the companion sites, and we euthanized 41 of them. Five of the 15 euthanized males $(33 \%)$ and 10 of the 26 euthanized females $(38 \%)$ were yearlings, based on tooth wear and consistent with body mass, testis size in males, and nipple and uterine size in females. All but 2 of the euthanized females were reproductive: 21 were pregnant, 2 had already given birth, and 1 had apparently just bred. The nonreproductive females included 1 yearling caught very early in the year (7 February) and an underweight adult (tooth wear class 3) caught on 17 February. The number of embryos in 20 reproductive females ranged from 8 to $14(\bar{x}=9.6 \pm$ 1.57). Embryo counts from 7 yearling females 
TABLe 1. Vegetative cover and number of Piute ground squirrels captured on 12 grids in the Snake River Birds of Prey National Conservation Area, 2003. Acronyms: ARTR-Artemisia tridentata; POSE-Poa secunda; BRTE-Bromus tectorum. Substrate includes bare ground, mosses, lichens, microbiotic crusts, and rocks.

\begin{tabular}{|c|c|c|c|c|c|c|c|}
\hline \multirow[b]{2}{*}{ Grid number } & \multirow{2}{*}{$\begin{array}{l}\text { Number of individual } \\
\text { squirrels captured }\end{array}$} & \multirow{2}{*}{$\begin{array}{l}\text { Total number } \\
\text { of captures }\end{array}$} & \multicolumn{5}{|c|}{ Percent cover } \\
\hline & & & ARTR & POSE & ARTR + POSE & BRTE & Substrate \\
\hline 141 & 22 & 31 & 22.5 & 20.0 & 42.5 & 0.0 & 40.0 \\
\hline 39 & 20 & 35 & 9.0 & 38.5 & 47.5 & 7.0 & 27.0 \\
\hline 104 & 16 & 21 & 5.0 & 17.5 & 22.5 & 0.8 & 45.8 \\
\hline 107 & 15 & 17 & 13.8 & 28.1 & 41.9 & 1.3 & 40.6 \\
\hline 246 & 11 & 17 & 0.0 & 2.5 & 2.5 & 0.6 & 70.0 \\
\hline 135 & 8 & 12 & 33.3 & 11.7 & 45.0 & 0.0 & 39.2 \\
\hline 71 & 5 & 7 & 0.0 & 14.3 & 14.3 & 53.6 & 19.6 \\
\hline 612 & 5 & 9 & 0.0 & 2.5 & 2.5 & 25.0 & 55.0 \\
\hline 613 & 5 & 11 & 0.0 & 0.0 & 0.0 & 49.2 & 43.8 \\
\hline 159 & 3 & 5 & 0.0 & 47.5 & 47.5 & 0.0 & 49.2 \\
\hline 530 & 1 & 1 & 4.0 & 0.0 & 5.0 & 37.5 & 55.8 \\
\hline 47 & 0 & 0 & 0.0 & 18.3 & 18.3 & 52.5 & 21.7 \\
\hline
\end{tabular}

$(\bar{x}=9.9)$ were similar to those from 13 adult females $(\bar{x}=9.4 ; t=0.74, P=0.47)$. Testes were scrotal in 9 euthanized males $(7$ adults, 2 yearlings), semiscrotal (neither abdominal nor fully descended) in 5 (3 adults, 2 yearlings), and abdominal in 1 yearling.

Twenty-eight of the individuals captured using focal animal sampling were near shrub grids and 27 were near grass grids. Due to unequal sampling effort, the number of individuals captured probably does not reflect relative abundance in the 2 habitat types. Eleven of 13 females trapped near shrub grids were $>1$ year old, but only 6 of the 13 females trapped near grass sites were $>1$ year old. One female carcass from a grass companion site was lost and could not be assigned to age class. Litter sizes of females, based on embryo counts, averaged $10.0 \pm 1.9$ in shrub habitats $(n=9)$ and $9.2 \pm 1.2$ in grass habitats $(n=11)$; differences were not significant $(t=1.12, P=$ 0.281 ). One nonreproductive female was associated with a grass site, and the other was near a grid with shrubs. We captured 13 males near grids dominated by grass habitats and 15 males near grids associated with shrubs. We did not euthanize males until after 7 February. Most of the males that we euthanized were from grass habitats ( 9 adults and 4 yearlings). We euthanized only 2 males ( 1 adult and 1 yearling) from shrub-dominated sites.

Masses of females captured on the trapping grids and companion sites ranged from $79 \mathrm{~g}$ to $254 \mathrm{~g}(\bar{x}=178 \pm 37.1 \mathrm{~g}, n=106)$ at the time they were first captured. Females in shrub habitats $(\bar{x}=184 \mathrm{~g})$ were significantly heavier $(t=2.64, \mathrm{df}=104, P=0.01)$ than females in grass habitats $(\bar{x}=164 \mathrm{~g})$. Masses of females in habitats with $\geq 25 \%$ cheatgrass cover $(\bar{x}=$ $155 \pm 33.3 \mathrm{~g}, n=21$ ) were significantly lower $(t=3.33, \mathrm{df}=93, P=0.001)$ than masses of females in habitats with $\geq 10 \%$ Poa $(\bar{x}=185 \pm$ $36.0 \mathrm{~g}, n=74$ ). Masses of males when first captured on grids and companion sites ranged from $76 \mathrm{~g}$ to $229 \mathrm{~g}$ and averaged $171 \pm 31.6 \mathrm{~g}$, $(n=59)$. Males in shrub habitats $(\bar{x}=179 \mathrm{~g})$ were significantly heavier $(t=2.62, \mathrm{df}=57, P$ $=0.01)$ than males in grass habitats $(\bar{x}=158$ g). Masses of males in habitats with $\geq 25 \%$ cheatgrass cover $(\bar{x}=155 \pm 34.9 \mathrm{~g}, n=19)$ were significantly lower $(t=3.15, \mathrm{df}=51, P$ $=0.003)$ than masses of males in habitats with $\geq 10 \%$ Poa $(\bar{x}=181 \pm 24.4 \mathrm{~g}, n=34)$. Female body masses showed a significant increase during the trapping period $(n=118, r=0.61$, $P<0.001)$ whereas male masses showed only a marginally significant increase $(n=62, r=$ $0.24, P=0.06$ ). Only 3 of the 166 squirrels that we captured and measured weighed less than $100 \mathrm{~g}$. One was a yearling male captured in March near a cheatgrass grid; 2 were nonreproductive females captured in February (1 in grass and 1 in shrub habitats).

We analyzed fecal nitrogen in 149 samples from individual squirrels collected throughout the study. Fecal nitrogen ranged from $1.0 \%$ to $5.5 \%$ in 149 fecal samples $(\bar{x}=2.6 \% \pm 0.9 \%)$. Mean fecal nitrogen showed no relation with body mass $(r=0.07$ for 98 females, $r=0.09$ for 51 males, $P$-values $>0.05)$, but percent nitrogen was higher in fecal pellets from males than those 
TABLE 2. Estimated number and densities of adult and yearling Piute ground squirrels by sex and habitat type on 12 trapping grids in the Snake River Birds of Prey National Conservation Area.

\begin{tabular}{|c|c|c|c|}
\hline & $\begin{array}{l}\text { Estimated number } \\
\text { of squirrels }\left(s_{\bar{x}}\right)\end{array}$ & $\begin{array}{c}\text { Effective trap area } \\
\text { (ha) }\end{array}$ & $\begin{array}{l}\text { Estimated density } \\
\left(\text { squirrels } \cdot \mathrm{ha}^{-1}\right)\end{array}$ \\
\hline \multicolumn{4}{|l|}{ ALL GRIDS } \\
\hline Both sexes & $182(28.1)$ & 63.8 & 2.85 \\
\hline Females & $133 \quad(26.3)$ & 60.7 & 2.19 \\
\hline Males & $49(9.8)$ & 70.4 & 0.70 \\
\hline \multicolumn{4}{|l|}{ SHRUB GRIDS } \\
\hline Both sexes & $148 \quad(27.9)$ & 31.9 & 4.64 \\
\hline Females & $112(26.2)$ & 30.4 & 3.69 \\
\hline Males & $36 \quad(9.6)$ & 35.2 & 1.02 \\
\hline \multicolumn{4}{|l|}{ GRASS GRIDS } \\
\hline Both sexes & $34 \quad(3.4)$ & 31.9 & 1.07 \\
\hline Females & $21 \quad(2.7)$ & 30.4 & 0.69 \\
\hline Males & $13(2.0)$ & 35.2 & 0.37 \\
\hline
\end{tabular}

from females $(t=2.72$, df $=147, P=0.007)$. Mean nitrogen content of fecal pellets from squirrels captured at grids with only grass cover $(2.69 \%)$ was similar to that of pellets from sites with shrub cover $(2.53 \%, t=1.02, \mathrm{df}=147, P$ $=0.31$ ); and pellets from sites dominated by cheatgrass had mean nitrogen contents identical to those dominated by Poa $(2.58 \%$ for both grass cover types).

Blood cultures were negative for $Y$. pestis and Bartonella in all Piute ground squirrels tested $(n=41)$. All squirrel serology samples $(n=43)$ also were negative for antibodies to $Y$. pestis. We analyzed 435 flea pools collected from squirrels. These pools included 1-5 fleas per pool, with each pool containing 1 or more individuals of a single species of flea collected from a particular host animal. A total of 614 individuals of Oropsylla tuberculata tuberculata (formerly Opisocrostis tuberculatus tuberculatus) were identified. These individual fleas were combined as described above into 273 pools and analyzed by PCR. We also analyzed 153 pools (282 individual fleas) of Thrassis francisi, 8 pools (8 individual fleas) of Rhadinopsylla sectilis, and 1 pool (1 individual flea) of Rhadinopsylla fraterna. All fleas tested negative for plague, but 1 flea (Thrassis francisi) tested positive for Bartonella. This flea was from a yearling female collected near Grid 159 on 14 February 2003.

\section{DisCussion}

Our sampling of Piute ground squirrels in late winter 2003 provided no evidence for a general population crash in 2002. Although squirrel numbers may have decreased from 2000-2001 levels, abundance did not appear to be extremely low, except at certain grass sites. Estimated squirrel densities in 2003 were within the ranges of densities reported by previous investigators in the NCA (Johnson and Nydegger 1984, Van Horne et al. 1997). The presence of yearlings in the 2003 population indicates that squirrels reproduced in 2002 and that at least some yearlings survived. The necropsies suggested that $33 \%$ of males and $38 \%$ of females were yearlings in 2003. This was slightly lower than Smith and Johnson's (1985) results from 1975 to 1981: $44 \%$ yearlings and 56\% adults. Reproductive rates in 2002 may have been lower than normal or, more likely, survival of young may have been somewhat depressed between 2002 and 2003. Body masses at emergence in 2003 did not suggest that surviving squirrels had been food-stressed in 2002; only 3 of 166 individuals had body masses $<100$ g.

Both yearling and adult squirrels appeared to be reproducing at or above normal rates in 2003. Mean litter size (9.6) in 2003 was larger than that reported by earlier studies. Mean annual litter size, based on counts of visible embryos and uterine placental scars, ranged from 7.15 to 9.11 from 1975 to 1981 (Smith and Johnson 1985) and was 8.1 in 1992 (Van Horne et al. 1997; $n=38$ ). Most yearling females bred in 2003, and their litter sizes were as large as those of adult females. This contrasts with Smith and Johnson's (1985) finding that pregnancy rates and mean litter 
sizes of yearling females were consistently smaller than those of adults from 1975-1981. Smith and Johnson (1985) reported that few yearling males had scrotal testes in the late 1970s and early 1980s, but at least 2 of 5 yearling males collected in 2003 had scrotal testes, and $2 \mathrm{had}$ semiscrotal testes.

Tests indicated that Piute ground squirrels had not been exposed to plague within the past year. Yersinia pestis has caused die-offs in other species of ground squirrels (Yensen and Sherman 2003), and sciurids in general appear to be quite susceptible to the disease. The 2 main fleas identified on NCA ground squirrels are known to be important vectors of plague under natural and laboratory conditions (Eskey and Haas 1940, Stark 1970). Therefore, if plague were to be introduced into the NCA population, squirrels might experience massive mortality. However, Messick et al. (1983) found antibody titers to plague in NCA badgers during a period with no ground squirrel die-offs. One flea tested positive for Bartonella in 2003; the effects of Bartonella on its hosts are uncertain.

We considered the possibility that predation may have depressed the ground squirrel population in 2002. Arctic ground squirrels (Spermophilus parryii) populations increased significantly at sites where predators had been excluded (Hubbs and Boonstra 1997, Karels and Boonstra 2000, Karels et al. 2000), but we have no evidence to suggest that higher predation pressure may have caused the early disappearance of squirrels in 2002. We have no reason to believe that predators were unusually abundant in 2002. Numbers of nesting Prairie Falcon pairs were only slightly higher in 2002 than the long-term average (USGS unpublished data), and we have no data on relative abundance of other raptors or of the mammalian and reptilian predators of ground squirrels. However, if predation pressure was exceptionally intense in 2002, then squirrel abundance in 2003 should have been exceptionally low. In fact, estimated densities were within the range of densities reported in other years (Johnson and Nydegger 1984, Van Horne et al. 1997). Additionally, there is no evidence that differential predation pressure on juvenile ground squirrels may have been responsible for the early disappearance of squirrels. Yearling-toadult ratios at emergence in 2003 were within the ranges reported for other years.
The most plausible explanation for the early disappearance of Piute ground squirrels in 2002 is that squirrels entered seasonal torpor early in that year. Piute ground squirrels normally are above ground through the end of June (Smith and Johnson 1985, Van Horne et al. 1997), but weather conditions can influence timing of immergence. NCA squirrels are known to respond to drought conditions, and the nature of their response depends on timing of the drought (Smith and Johnson 1985, Van Horne et al. 1997).

Precipitation at the Boise, Idaho, Airport Station was near or above normal through January 2002, and rainfall was very low from February through May (WRCC 2002). Above average temperatures and lack of rainfall during late April and early May caused vegetation to dry up earlier than normal in 2002 (Yensen unpublished data). Ground squirrels are not known to feed on dry vegetation, and immergence into torpor often coincides with drying of succulent green vegetation. Because squirrels had probably been able to gain weight early because of good soil moisture in March and early April 2002, it likely was advantageous for squirrels to immerge as soon as they reached adequate masses for overwinter survival. Other studies have found that ground squirrels are generally food limited (Reynolds and Turkowski 1972, Dobson and Kjelgaard 1985, Dobson and Murie 1987, Rickart 1988, Dobson and Oli 2001), and a decrease in quality of vegetation would make further aboveground activity unprofitable.

Our findings confirm earlier reports (Yensen et al. 1992, Van Horne et al. 1997) that shrub habitats provide more favorable environments for squirrels than grass habitats. Estimated population densities of nonjuvenile Piute ground squirrels were more than 4 times higher on the shrub grids than on the grass grids in 2003. Although estimated population densities on shrub grids in 2003 were within the ranges of those reported by Van Horne et al. (1997) for sagebrush sites in 1991-1994, the estimated population densities for grass sites in 2003 were lower than any reported by Van Horne et al. (1997) for grass sites in 1991-1994. Van Horne et al. (1997) found that drought adversely affected squirrels more in altered grass communities than in native shrub habitats. Low population densities at grassland sites in 2003 
following the 2002 drought are consistent with this finding. Conversion of shrublands to exotic annual communities seems to have caused wider annual fluctuations in ground squirrel numbers (Yensen et al. 1992, Van Horne et al. 1997).

Body masses of both male and female Piute ground squirrels were higher in shrub than in grass habitats, and they were higher at sites dominated by native perennial Poa spp. rather than exotic annual cheatgrass. It is not clear whether differences in body mass reflected differences in condition, differences in reproductive phenology, or if they were associated with differences in yearling-to-adult ratios in the 2 habitat types. An analysis of fecal pellets suggested that dietary nitrogen was similar among sites during the period we sampled. Plant nitrogen is typically high during growth periods, but nitrogen levels drop sharply as tissue growth wanes and as plants senesce (Mattson 1980). Because annual plants in the NCA senesce earlier than native perennials, we might expect to see differences in ground squirrel fecal nitrogen among habitats later in the season (R. Rosentreter, BLM, personal communication).

Changes in ground squirrel abundance associated with habitat change have the potential to affect the predators that depend on them for food (USDI 1979). Continued conversion of native sagebrush/bluegrass communities to cheatgrass in the NCA likely will adversely affect ground squirrels. This could have important negative ecosystem-level consequences for soil fertility, plant diversity, and productivity (Tilman 1999, 2000, Yensen and Sherman 2003). Exotic plants are facilitated by exotic herbivores (domestic cattle and sheep) and decreases in native herbivores (Parker et al. 2006). Decrease or loss of ground squirrel populations could be expected to further facilitate exotic plant dominance in this ecosystem.

In addition, long-term changes in ground squirrel breeding chronology may have important implications for their predators, particularly Prairie Falcons. Earlier immergence of ground squirrels may reduce the food available for late nesting falcons and for falcons during the critical post-fledging period. Additional monitoring is needed to determine if shifts in ground squirrel reproductive chronology are continuing, and if nesting Prairie Fal- cons respond to these changes by altering their breeding chronology.

\section{ACKNOWLEDGMENTS}

We are grateful to the Lower Snake River District, Bureau of Land Management, and John Sullivan, manager of the NCA, for funding this study. This study would not have been possible without our dedicated field technicians: Jason Ferrell, Leigh Greenwood, Eric Hynes, and Major Waltman. Steve Alsup assisted with trapping and Kristen Ross sampled vegetation on the trapping grids. James Munger of Boise State University provided logistical assistance and training in blood sampling techniques. Justin Barrett provided advice on field techniques. Teresa Tarifa assisted with necropsies and provided ideas for discussion, and Kathy McCoy assisted us in developing charts and tables. We also thank Bruce Davitt for performing the fecal nitrogen analysis. We could not have completed the population analysis without assistance from Ken Burnham of the Colorado Cooperative Wildlife Research Unit. We thank F. Stephen Dobson, John Sullivan, Graham Smith, and 2 anonymous reviewers for constructive reviews of earlier versions of the manuscript.

\section{Literature Cited}

Chu, M.C. 2000. Laboratory manual of diagnostic tests. U.S. Department of Health and Human Services, Centers for Disease Control and Prevention, Atlanta, GA. 129 pp.

Diller, L.V., AND D.R. Johnson. 1988. Food habits, consumption rates, and predation rates of western rattlesnakes and gopher snakes in southwestern Idaho. Herpetologica 44:228-233.

Dobson, F.S., AND J.D. KJELGaARD. 1985. Influence of food resources on population dynamics in Columbian ground squirrels. Canadian Journal of Zoology 63: 2105-2109.

Dobson, F.S., AND J.O. MuRIE. 1987. Interpretation of intraspecific life history patterns: evidence from Columbian ground squirrels. American Naturalist 129:382397.

Dobson, F.S., AND M.K. OLI. 2001. The demographic basis of population regulation in Columbian ground squirrels. American Naturalist 158:236-247.

Eskey, C.R., AND V.H. HAas. 1940. Plague in the western part of the United States. Public Health Bulletin No. 254:1-82.

Herrick, J.E., J.W. Van Zee, K.M. Havstad, L.M. BurkELL, AND W.G. WhitFord. 2005. Monitoring manual for grassland, shrubland, and savanna ecosystems. USDA-ARS Jornada Experimental Range, Las Cruces, 
NM. ISBN 0-975555-0-0. Available from: http://usdaars.nmsu.edu/.

HubBs, A.H., AND R. BoOnstRa. 1997. Effects of food and predators on the home range sizes of arctic ground squirrels (Spermophilus parryii). Canadian Journal of Zoology 76:592-596.

Johnson, D.R., AND N.C. NydegGer. 1984. Final report: abundance and demography of prey populations in the Snake River Birds of Prey Area. Unpublished report by Department of Biological Sciences, University of Idaho for U.S. Department of the Interior, Bureau of Land Management, Contract \#YA-553CT2-109.

Karels, T.J., AND R. BoOnstra. 2000. Concurrent density dependence and independence in populations of arctic ground squirrels. Nature 408:460-463.

Karels, T.J., A.E. Byrom, R. Boonstra, and C.J. Krebs. 2000. The interactive effects of food and predators on reproduction and overwinter survival of arctic ground squirrels. Journal of Animal Ecology 69:235-247.

Kosoy, M.Y., E.K. Saito, D. Green, E.L. Marston, D.C. Jones, AND J.E. Childs. 2000. Experimental evidence of host specificity of Bartonella infection in rodents. Comparative Immunology, Microbiology and Infectious Diseases 23:221-238.

MatTson, W.J., JR. 1980. Herbivory in relation to plant nitrogen content. Annual Review of Ecology and Systematics 11:119-161.

Messick, J.P., And M.G. Hornocker. 1981. Ecology of the badger in southwestern Idaho. Wildlife Monographs 76:1-53.

Messick, J.P., G.W. Smith, AND A.M. Barnes. 1983. Serologic testing of badgers to monitor plague in southwestern Idaho. Journal of Wildlife Diseases 19:1-6.

Otis, D.L., K.P. Burnham, G.C. White, AND D.R. ANDERSON. 1978. Statistical inference from capture data on closed animal populations. Wildlife Monographs 62:1-135.

Parker, J.D., D.E. Burkepile, and M.E. Hay. 2006. Opposing effects of native and exotic herbivores on plant invasions. Science 311:1459-1461.

Reynolds, H.G., AND F. TuRKowsKi. 1972. Reproductive variations in the round-tailed ground squirrel as related to winter rainfall. Journal of Mammalogy 53: 893-898.

Rickart, E.A. 1988. Population structure of the Piute ground squirrel (Spermophilus mollis). Southwestern Naturalist 33:91-96.

Schooley, R.L., B. Van Horne, and K.P. Burnham. 1993. Passive integrated transponders for marking freeranging Townsend's ground squirrels. Journal of Mammalogy 74:480-484.

SCHWARZ, C.J., AND A.N. ARNASON. 1996. A general methodology for the analysis of capture-recapture experiments in open populations. Biometrics 52:860-873.

Smith, G.W., AND D.R. Johnson. 1985. Demography of a Townsend ground squirrel population in southwestern Idaho. Ecology 66:171-178.

StaRK, H.E. 1970. A revision of the flea genus Thrassis Jordan 1933 (Siphonaptera: Ceratophyllidae) with observations of ecology and relationship to plague.
University of California Publications in Entomology 53:1-184.

Steenhof, K., And M.N. Kochert. 1985. Dietary shifts of sympatric buteos during a prey decline. Oecologia 66:6-16.

1988. Dietary responses of three raptor species to changing prey densities in a natural environment. Journal of Animal Ecology 57:37-48.

Stevenson H.L., Y. Bai, M.Y. Kosoy, J.A. Montenieri, J.L. Lowell, M.C. Chu, and K.L. Gage. 2003. Detection of novel Bartonella strains and Yersinia pestis in prairie dogs and their fleas (Siphonaptera: Ceratophyllidae and Pulicidae) using multiplex PCR. Journal of Medical Entomology 40:329-337.

Tilman, D. 1999. The ecological consequences of changes in biodiversity: a search for general principles. Ecology 80:1455-1474.

.2000. Causes, consequences and ethics of biodiversity. Nature 405:208-211.

[USDI] U.S. Department of the Interior. 1979. Snake River Birds of Prey Special Research Report to the Secretary of the Interior. USDI, Bureau of Land Management, Boise District, Boise, ID.

1996. Effects of military training and fire in the Snake River Birds of Prey National Conservation Area. U.S. Geological Survey, Biologial Research Division, Snake River Field Station, Boise, ID, BLM/ IDARNG Research Project Final Report.

Van Horne, B., G.S. Olson, R.L. SchoOley, J.G. Corn, AND K.P. BuRnham. 1997. Effects of drought and prolonged winter on Townsend's ground squirrel demography in shrubsteppe habitats. Ecological Monographs 67:295-315.

WaTTS, S.E., AND S.T. KNICK. 1996. The influence of vegetation, soils, and disturbance on Townsend's ground squirrel abundance. BLM/IDARNG Research Project Final Report. Volume 2, Part 2. Boise, ID.

[WrCC] Western Regional Climate Center. 2002. Climate data. Available from: http://www.wrcc.dri.edu/ climatedata.html

White, G.C., AND K.P. BuRnham. 1999. Program MARKestimation from populations of marked animals. Bird Study 46 (supplement):120-138.

Yensen, E. 1991. Taxonomy and distribution of the Idaho ground squirrel, Spermophilus brunneus. Journal of Mammalogy 72:583-600.

2000. Conservation survey of three species of western "small-eared" ground squirrels. Unpublished report for U.S. Fish and Wildlife Service, Boise, ID.

Yensen, E., D.L. Quinney, K. Johnson, K. Timmerman, and K. Steenhof. 1992. Fire, vegetation, and population fluctuations of Townsend's ground squirrels. American Midland Naturalist 128:299-312.

Yensen, E., AND P.W. Sherman. 2003. Ground squirrels. Pages 211-231 in G. Feldhamer, B. Thompson, and J. Chapman, editors, Wild mammals of North America. 2nd edition. Johns Hopkins University Press, Baltimore, MD.

Received 24 August 2005 Accepted 14 April 2006 